\title{
Mental Intelligency and the Ability of Children with Autism in Producing Verbal Expressions: A Case Study at State School of Exceptional Children in Surakarta City
}

\author{
Ahfi Hikmawati ${ }^{1}$, Djatmika ${ }^{2}$ \\ 19ahfihikmawati02@gmail.com; ${ }^{2}$ djatmika@staff.uns.ac.id \\ ${ }^{1,2}$ Universitas Sebelas Maret, Surakarta, Indonesia
}

\begin{abstract}
The article discusses the ability of children with autism to produce types of language units and types of utterances. Data in the forms of language units and utterances were collected from interaction performed by teachers and students with autism at State School for Exceptional Children in Surakarta. The former is represented by words, phrases, and clauses, while the latter is related to types of speech act the students can exploit in their interaction. The results show that the ability in producing language units and types of utterances depends on the mental condition of each student. Students who are classified as verbal children and have good mental condition tend to be able to produce more various language units and utterances; whereas those with lower inteligence tend to have limited varieties of units and utterances.
\end{abstract}

Keywords: children with autism, language units, utterances, pragmatics.

\section{Introduction}

Children with autism basically have limited nerve function, mind and development so that they tend to be different from normal children who have complete nerves and thoughts. Yuwono states there are three types of disorders, such children generally experience, i.e. behavior, social interaction, and communication (language). ${ }^{1}$ Previous research showed that children with autism who attend special schools are able to produce language units in the form of words, phrases and clauses. ${ }^{2}$ Moreover, each of these language units actually represents speech act that is used to respond to stimulants given by the teacher. In connection with this phenomenon, this article presents two things related to the productivity of these children, namely the type of language units and the types of speech acts that are accommodated by these language units. The uniqueness of the verbal language of autistic children is interesting to study because each child with this condition has different verbal abilities. To have an interaction with the children requires the focus of eye contact from teacher--without it, the communication process tends not to run smoothly. The child is unable to pay attention, or to respond to a stimulant if it is not preceded by first eye contact, as they experience problems in aspects of behavior and social interaction.

When the focus of the child's eye contact is established, the child can produce language in accordance with the desired goals. Children are able to produce language in the form of words/phrases/clauses/sentences. In addition, each language unit they produce in general 
accommodate illocutionary meaning in the form of utterances or speech acts. Thechildren ability to produce these verbal expressions can not be separated from the role of the teacher in giving verbal as well as non verbal stimulants for such production. ${ }^{3}$

\section{Literature Review}

\subsection{Language Units}

The form of language units is expressed syntactically. According to Verhaar (2012: 97-161) syntax is a grammar that discusses the relationship between words in utterances. ${ }^{5}$ Put in other words, syntax involves grammatical relationships between words in sentences. A word is a language unit in the form of free morpheme. There are two types of words, such as lexical and grammatical words. Moreover, according to their categories, words are classiffied into ten. Meanwhile, Ramlan suggests that a phrase is a grammatical unit consisting of two or more words and has a unit that does not exceed the limits of the elemental clause functions. ${ }^{4} \mathrm{~A}$ clause is a grammatical unit consisting of subject and predicate accompanied by object, supplement, and description or not. Sentences are grammatical units that are limited by a long pause accompanied by a final note down or up.

\subsection{Speech Acts}

Utterances are accommodated by clauses, even though they can be expressed in the form word, phrase, clause, or sentence. Utterances are accommodated by clauses, even though they can be expressed in the form word, phrase, clause, or sentence. There are five major classifications for speech acts according to Searle which are followed by various experts, i.e. assertive, directive, commissive, expressive, and declarative speech acts. ${ }^{6}$ Djatmika describes the five major classifications ${ }^{7}$, as follow.

a. Assertive speech acts are related to propositions, both true and false propositions.

b. Directive speech acts are speech acts that aim to make the speech partner do something or not do something.

c. Commissive speech act is the opposite of directive. Commision speech acts are speech acts carried out by the speaker by making a commitment to take action in the future.

d. Expressive speech act occurs when a speaker expresses his feelings and emotional condition to the second person (speech partner).

e. Performative speech act is exploited to change the word such as declaring, baptizing, naming, marring, appointing, sentencing, and so on.

\section{Method}

Data for the research were utterances performed by children with autism ad their teachers in a learning process. The class was observed and recorded, and then the utterances were transcribed. They were then analised to reveal the types of language units they produced and what types of speech act the units have. The results of the analysis then would represent the verbal quality of the children in the forms of types of language units and illocutionary meaning behind each of the unit. 


\section{Result and Discussion}

\subsection{Language Units and Speech Acts}

There were five students with autism in the observed class. Three students were classified as students with active verbal abilities, while the two were classified as passive verbal. Two teachers were involved in the learning process. Parts of interactions that occur in this class are presented to show the verbal abilities of students in producing language units and what types of speech acts are accommodated by each of these language units.

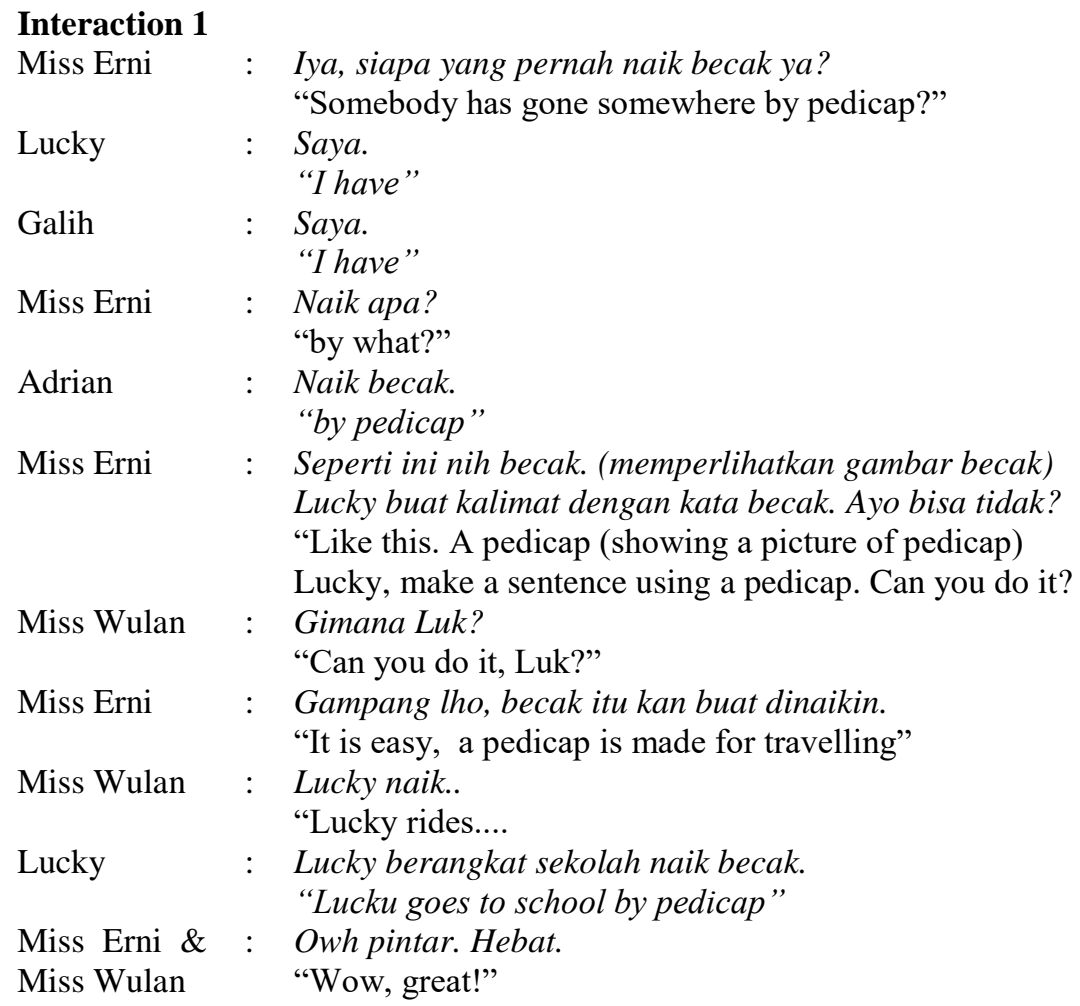

The first language unit performed by two students, named Galih and Lucky was a pronoun saya "I". This words was executed by the children to respond to Miss Erni question whether they have had taken a pedicap or not. Another utterance was represented in a verbal phrase naik becak "ride a pedicap" performed by Adrian as the next response for the initiating question about riding a pedicap. For the same question, another student who showed best mental quality provided a sentence "Lucky berangkat sekolah naik becak "Lucky goes to school by pedicap", even though this production was stimuated by the two teachers. Miss Erni read a text from a book and asked who ever rides a pedicab followed by commanding Lucky to make a sentence with the word pedicab Verbal expressions produced by children in this interaction were performed after the teachers read a short text, gave examples of pedicap pictures, stimulated them to produce and made eye contact to the children.

\section{Interaction 2}




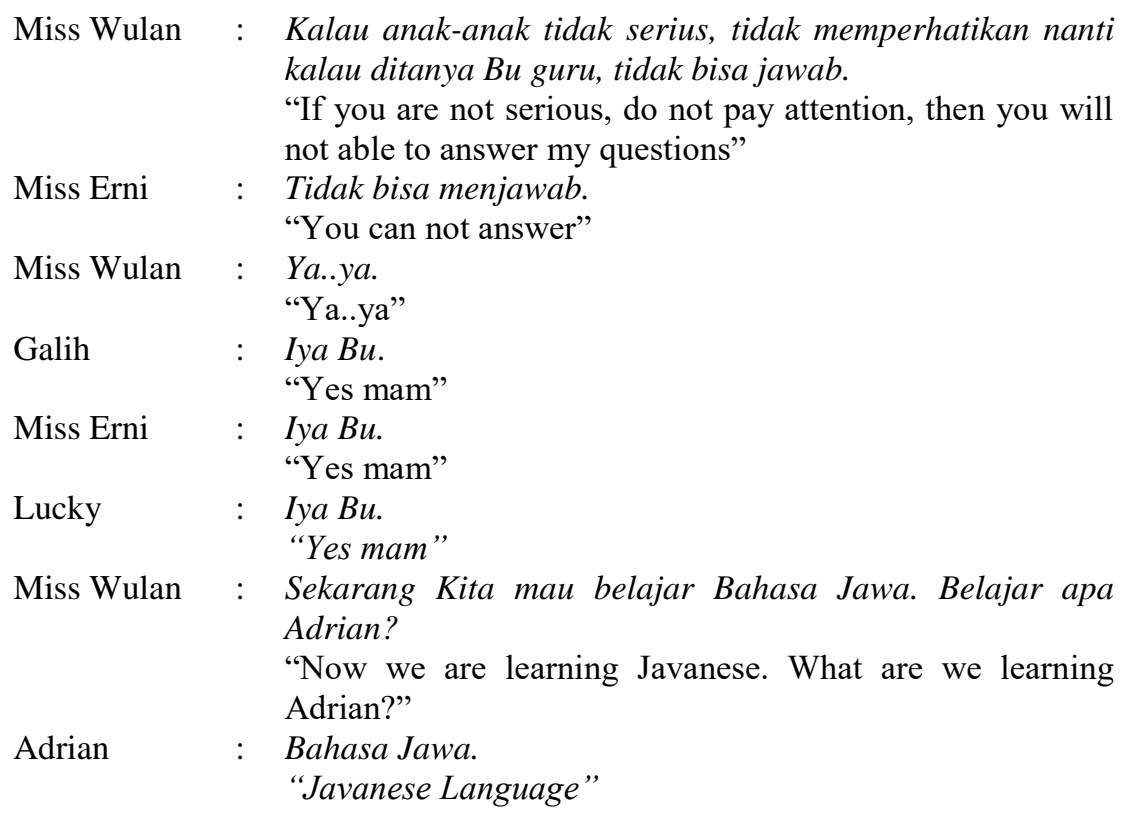

Interaction 2 presents a noun phrase Bahasa Jawa "Javanese Language" produced by one of the students, named Adrian for a stimulant provided by Miss Wulan in an utterance questioning the next lesson for the class. Miss Wulan asked Adrian to stimulate him to interact with her and to make him participate in the learning process. Similar to what the teachers did in Interaction 1 , verbal expressions produced by the children were the results of encouragement in the forms of verbal as well as verbal exploitation.

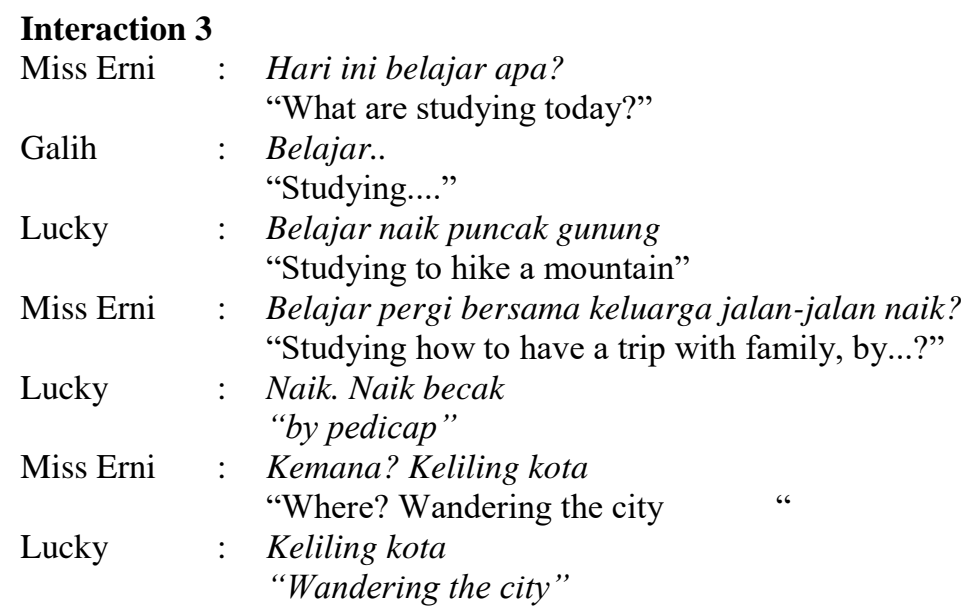

This interaction presents verbal production performed by the students in the form of verbs, i.e. belajar "study", and naik "ride"; verbal phrases keliling kota "go around naik becak "ride a pedicap", and belajar naik puncak gunung "learn to hike a mountain" which were produced by Lucky and Galih as responses to Miss Erni learning evaluation on that day. All of these elliptic expressions represent utterances with illocutionary meaning of answering the children 
provided for the teacher's questions. Multimodal stimulating strategies were applied by the teacher in this part of the learning process. Meanwhile, the following short interaction displays only word production performed by the students.

\begin{tabular}{|c|c|c|}
\hline \multicolumn{3}{|l|}{ Interaction 4} \\
\hline Miss Erni & : & $\begin{array}{l}\text { Tangannya dilipat. Tirukan! } \\
\text { "Cross your hands. Copy me!" }\end{array}$ \\
\hline Miss Wulan & : & $\begin{array}{l}\text { Tirukan yuk! } \\
\text { "Copy me, please!" }\end{array}$ \\
\hline Miss Erni & $:$ & $\begin{array}{l}\text { Becak. } \\
\text { "Pedicap" }\end{array}$ \\
\hline Lucky & : & $\begin{array}{l}\text { Becak. } \\
\text { "Pedicap" }\end{array}$ \\
\hline Adrian & $:$ & $\begin{array}{l}\text { Becak. } \\
\text { "Pedicap" }\end{array}$ \\
\hline Miss Erni & $:$ & $\begin{array}{l}\text { Tirukan be.. } \\
\text { "Copy me, be... }\end{array}$ \\
\hline Fahri & $:$ & $\begin{array}{l}\text { cak. } \\
\text {..."cak" }\end{array}$ \\
\hline Miss Erni & $:$ & $\begin{array}{l}\text { Iya. Be..cak. Apa? } \\
\text { "Yes, pedicap. What? }\end{array}$ \\
\hline Rafa & $:$ & $\begin{array}{l}\text { Be..cak. } \\
\text { "Pedicap" }\end{array}$ \\
\hline Miss Erni & $:$ & $\begin{array}{l}\text { Yang kedua. Kota. } \\
\text { "Next, Town." }\end{array}$ \\
\hline Lucky & $:$ & $\begin{array}{l}\text { Kota. } \\
\text { "Town" }\end{array}$ \\
\hline Adrian & $:$ & $\begin{array}{l}\text { Kota. } \\
\text { "Town" }\end{array}$ \\
\hline Galih & $:$ & $\begin{array}{l}\text { Kota } \\
\text { "Town" }\end{array}$ \\
\hline Miss Wulan & $:$ & $\begin{array}{l}\text { Kota. } \\
\text { "Town" }\end{array}$ \\
\hline Miss Erni & : & $\begin{array}{l}\text { Ko.. } \\
\text { "Кo.. }\end{array}$ \\
\hline Fahri & $:$ & "..ta.." \\
\hline Miss Erni & $:$ & $\begin{array}{l}\text { Pintar. Ko..ta. Apa? } \\
\text { "Smart. Town. What?" }\end{array}$ \\
\hline Rafa & $:$ & $\begin{array}{l}\text { Ko..ta. } \\
\text { "Town" }\end{array}$ \\
\hline Miss Erni & : & $\begin{array}{l}\text { Pintar. } \\
\text { "Smart" }\end{array}$ \\
\hline
\end{tabular}

As Miss Erni just stimulated the children to copy what she uttered, they only produced words to respond to what the teacher wanted. They imitated words the teacher provided to them, such as becak "pedicap" and kota "town". Everybody performed well for these words except Rafa and Fahri who are classiffied as having passive verbal performance. They got difficulty in imitating the words provided by the teacher. Put in other words the language production of each 
child in Interaction 4 is different. The language production showed by Lucky, Adrian, and Galih when speaking the word becak and kota was very clear and precise in responding without having to be repeated. In contrast, Rafa and Fahri needed more stimulation from their teacher to produce such words. Even though they only imitated a language unit presented by the teacher, the words they produced represent an act of imitating.

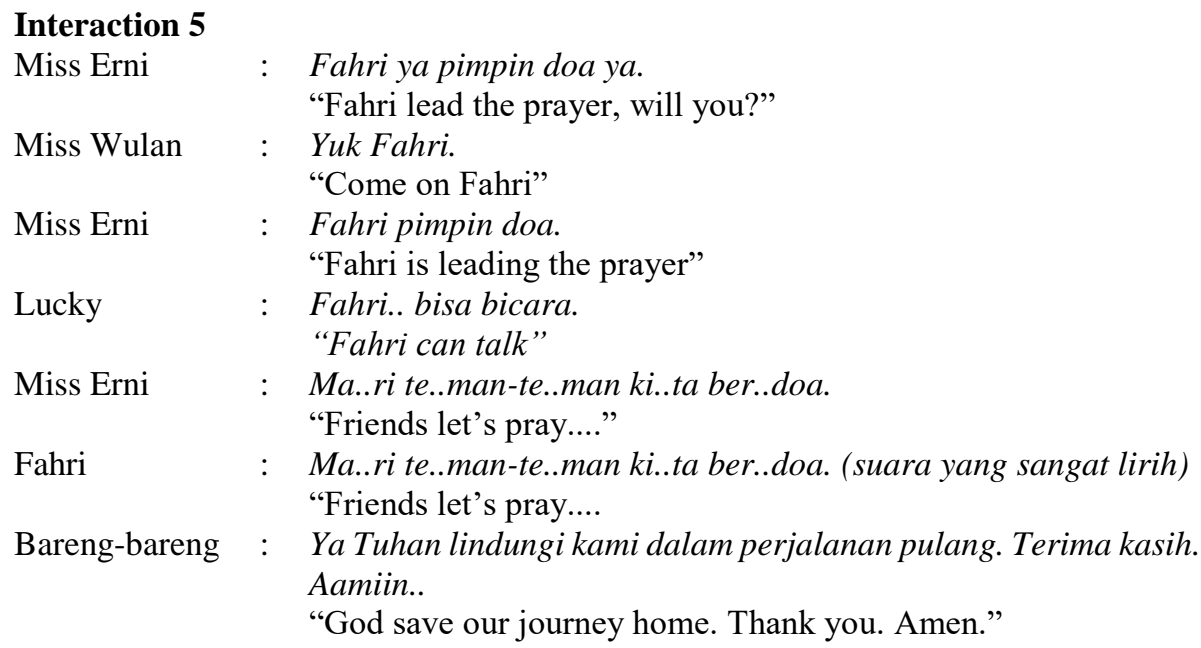

The same cases happened to one of the passive verbal child, named Fahri in Interaction 5. He only can imitate what his teacher said. In this short interaction, the teachers wanted Fahri to lead the class for praying to go home. He did what the teachers ordered him, imitating expression to lead the class. The expression was in the form of sentence. Meanwhile, Lucky the active verbal one supported the teachers by telling that Fahri can talk. He said Fahri..bisa bicara. In saying this, Lucky actually also supported his mate Fahri to do the teachers' order, as in the execution Fahri got difficulty in accomplish the order, so that the teachers must encourage him by cutting the expression in syllables to accommodate the proces of imitation.

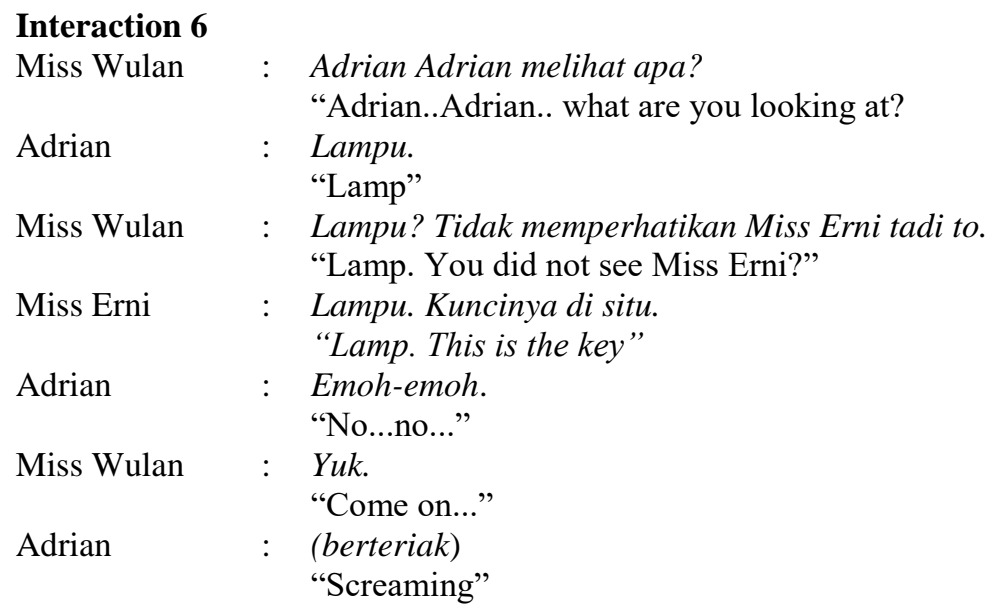


Two types of speech acts were performed by a student named Andrian in Interaction 6 such as answering and rejecting. The first was executed by the child to respond to a question delivered by his teacher. The second was produced by Adrian to refuse an offer given by the teachers by saying Kuncinya di situ "The key is over there". The key was offered by Miss Erni as a form of warning so that Adrian would pay attention and not daydream. They already have an agreement if a student does not pay attention or day dream during the class s/he will be put into a room and being locked. The warning from Miss Erni and Miss Wulan was responded by Adrian by rejecting the key - and this speech act was repeated when the teachers teased him by inviting him to go into the room. Adrian screamed aloud to represent his rejection. The speech acts performed by the child in this interaction were accommodated by words.

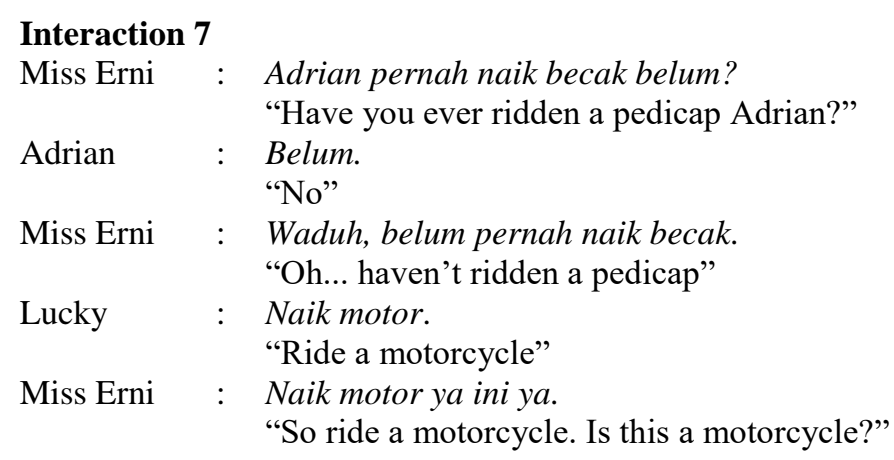

Interaction 7 presents two language units, i.e. word and phrase which were produced by the children. The word was performed by Adrian to respond to a question delivered by the teachers, while the phrase naik motor "ride a motorcycle" was performed by Lucky to tell the teacher that his friend, Adrian has ever ridden a motorcycle. In such a case, the word and the phrase represent elliptic utterances, as each can provide meaning as "No, I have never ridden a pedicap", and "Adrian has ever ridden a motorcycle."

\section{Interaction 8}

Miss Erni

Galih

Miss Erni

Lucky

Miss Wulan

Lucky

Miss Wulan
: Naik motor ya ini ya. Galih sudah pernah naik becak? "Ride a motorcycle like this? Galih, have your ridden a pedicap?"

: Belum

"Not yet"

: Owh kamu sudah pernah naik becak ya.. Putra juga pernah naik becak. (sambil mendekati Putra yang sejak tadi berteriak sendiri) Oke. Bersama Ayah.

"Oh.. you have never ridden a pedicap. Putra has also ridden a pedicap. With his father"

: Jose naik becak "Jose rode a pedicap"

: Jose, owh ya.. Jose pernah naik becak "Jose, Oh ya. Jose rode a pedicap"

: Jose pergi ke sekolah naik becak "Jose goes to school by pedicap"

: Becak itu rodanya ada? Tiga "How many wheels does a pedicap have? Three" 
Fahri

: Tiga

"Three."

Statements and questions were delivered by the teachers to stimulate the children to give responses. Two active verbal children made responses in the form of word and clauses. The word was given by Galih and the clauses were presented by Lucky - the best student in the class. The former child produced the word to answer the teacher's question, while the latter child deliberately and initially produced two clauses to tell the teacher about his frind's experience. Similar to other previous interactions, the stimulation presented by the teachers to the children was carried out multimodally. They mainly exploit verbal expression and supported by other modes such as body language, facial gestures, and learning aids.

\subsection{Discussion}

The ability to produce language units and speech acts of students with autism in this study is related to the condition of their mental intelligence. In other words, there are three aspects that can be linked in describing the ability of children with autism to interact in the classroom learning process, namely the level of student intelligence, language units, and the types of speech acts that are produced. To describe these three aspects, the table below can be seen as a reference.

Level of Intelligence, Language Units, Speech Acts Produced by Students with Autism

\begin{tabular}{|c|c|c|c|c|c|c|}
\hline \multirow[t]{2}{*}{ Name } & \multicolumn{2}{|c|}{ Classification } & \multicolumn{3}{|c|}{ Language Units } & \multirow[t]{2}{*}{ Types of Speech Acts } \\
\hline & $\begin{array}{l}\text { Active } \\
\text { Verbal }\end{array}$ & $\begin{array}{l}\text { Passive } \\
\text { Verbal }\end{array}$ & Word & Phrase & Sentence & \\
\hline Lucky & $\sqrt{ }$ & & 4 & 4 & 4 & $\begin{array}{ll}- & \text { answering }(4 \mathrm{x}) \\
- & \text { accomplishing an } \\
& \text { order }(1 \mathrm{x}) \\
- & \text { acknowledging } \\
& (1 \mathrm{x}) \\
- & \text { imitating }(2 \mathrm{x}) \\
- & \text { tellin }(4 \mathrm{x})\end{array}$ \\
\hline Galih & $\sqrt{ }$ & & 6 & & & $\begin{array}{ll}- & \text { answering }(3 \mathrm{x}) \\
- & \text { acknowledging } \\
& (1 \mathrm{x}) \\
- & \text { imitating }(2 \mathrm{x})\end{array}$ \\
\hline Andrian & $\sqrt{ }$ & & 5 & 3 & & $\begin{array}{ll}- & \text { answering }(5 x) \\
- & \text { imitating }(2 \mathrm{x}) \\
- & \text { rejecting }(1 \mathrm{x})\end{array}$ \\
\hline Fahri & & $\sqrt{ }$ & 2 & & 1 & $\begin{array}{ll}- & \text { imitating (2) } \\
- & \text { asking }(1 \mathrm{x})\end{array}$ \\
\hline Rafa & & $\sqrt{ }$ & 2 & & & - $\quad$ imitating $(2 \mathrm{x})$ \\
\hline
\end{tabular}

The table above shows that there are five (5) students involved in the learning process observed in this study. Although all students are classified as verbal students, in the class three students can be categorized as active verbal students, while the other two can be called as passive 
verbal students. This active and passive status is identical to their intelligence level - active tends to have a higher level of intelligence compared to passive verbal students.

As presented in the table above, three active verbal students showed a greater number of language units produced than passive verbal students. Each of them produces 12, 6, and 8 language units - thus, the three students produce an average of 9 language units. Furthermore, the level of language units is also influenced by this level of intelligence. Active verbal students tend to be able to produce three units - words, phrases, and sentences, while passive students tend to produce low-unit language (words). There is a passive verbal student who produces a sentence, but this language unit is produced through the process of imitating the teacher expression, not a independent production.

Furthermore, when it is associated with the type of speech act that is accommodated by the language unit, then the role of the intelligence level of these students is increasingly clear. Because the language unit accommodates the meaning of utterances or speech acts, active verbal students tend to be able to produce greater number of utterances than their passive peers. In addition, active verbal students are able to produce more various utterances - they can make three to five different types of speech acts. Meanwhile, two students who are passive are only able to imitate utterances. More than that, there is an active verbal student who is also able to produce an initating utterance, that is to tell, whereas the other utterances produced by his mates are responding ones. This quality can indicate that the student has the highest verbal intelligence. This phenomenon should be an input for teachers in designing teaching techniques for students with autism. Stimulating action still needs to be done to encourage students involved in the process of producing units of language, which contains the illocutionary meaning of a speech that is accommodated.

\section{Conclusion}

The results of this study indicate that the language and speech production of each child is different. Lucky and Adrian are able to produce language units at the level of words, phrases, sentences. Galih was only able to produce language units at the level of words and phrases, while Fahri and Rafa only produced words with stimulation from the teachers. All language units produced by the children actually represent three classifications of speech acts, namely assertive as they tell, acknowledge, imitate, and answer question; commissive as one of the child rejected an offer and an invitation; and a directive as one of them asked the others to pray.

\section{References}

[1] Yuwono, J. Memahami anak autistik (Kajian Teoretik dan Empirik). Bandung: Alfabeta. 2012

[2] Ahfi, Djatmika, \& Sumarlam. Expressive skill of children with autism: A psycholinguistics study. Humanus. Vol 18(1). 2019. Page 101-113.

[3] Djatmika, Wibowo, A.H.,Sugini,Halim, H. \& Mohamad, B. Multimodal strategies in teaching children with autism: A discourse analysis. Sys Rev Pharm Vol 11(2). 2020. Page 219-229

[4] Ramlan. Ilmu Bahasa Indonesia Sintaksis. Yogyakarta: C.V.Karyono. 2005

[5] Verhaar, J.W.M. Asas-asas Linguistik Umum. Yogyakarta: Gadjah Mada University Press. 2012. Page 97-161

[6] Searle, John. R. Expression and Meaning: Studies in the Theory of Speech Acts. Cambridge: Cambridge University Press. 2015. Page 12-16

[7] Djatmika. Mengenal pragmatik yuk!?. Yogyakarta: Pustaka Belajar. 2016. Page 16-19 